\title{
Restrictions of Speech Because of its Content: The Peculiar Case of Subject-Matter Restrictions
}

\author{
Geoffrey R. Stone $\dagger$
}

Governmental restrictions of expression may be divided into two general categories-content-neutral restrictions and contentbased restrictions. ${ }^{1}$ Content-neutral restrictions restrict communication without regard to the message conveyed. Laws prohibiting noisy speeches near a hospital, banning the erection of any billboards in residential communities, or requiring disclosure of the names of leafleteers are examples. In judging the constitutionality of such restrictions, the Supreme Court engages in a balancing of first amendment interests against competing government concerns. ${ }^{2}$ Content-based restrictions, on the other hand, restrict communication because of the message conveyed. Laws prohibiting the publication of specific types of "confidential" information, forbidding the hiring of teachers who advocate the violent overthrow of the government, or banning the display of the swastika in certain neighborhoods illustrate this type of restriction. ${ }^{3}$

† Associate Professor of Law, The University of Chicago. The author would like to thank Paul Bator, Gerhard Casper, Charles DiSalvo, Walter Hellerstein, William Hodes, Douglas Laycock, and Robert Vollen for their helpful comments on an earlier draft of this article.

' Compare, e.g., Grayned v. City of Rockford, 408 U.S. 104 (1972) with Police Dep't v. Mosley, 408 U.S. 92 (1972). See also FCC v. National Citizens Comm. for Broadcasting, 436 U.S. 775, 800-01 (1978); Erznoznik v. City of Jacksonville, 422 U.S. 205, 209 (1975). For a somewhat more comprehensive discussion of this distinction, see L. TrIBE, AMErIcan Const7TUTIONAL LAw \$§ 12-2 to -3 (1978). See also United States v. O'Brien, 391 U.S. 367, 377, 382 (1968); Ely, Flag Desecration: A Case Study in the Roles of Categorization and Balancing in First Amendment Analysis, 88 HARv. L. Rev. 1482, 1496-502 (1975); Williams, Subjectivity, Expression and Privacy: Problems of Aesthetic Regulation, 62 Minn. L. REv. 1, 24-28 (1977).

2 See, e.g., Pell v. Procunier, 417 U.S. 817 (1974); Grayned v. City of Rockford, 408 U.S. 104 (1972); Talley v. California, 362 U.S. 60 (1960); Schneider v. State, 308 U.S. 147 (1939). For an analysis of the sorts of variables deemed relevant and the way in which the Court attempts to define the nature and operation of this balancing process, see L. TriBE, supra note $1, \& 12-20$.

3 The most obvious and most common form of content-based restriction consists of government action-legislative, executive or judicial-that on its face expressly accords differential treatment to the expression of certain specified messages, ideas, or information. Familiar examples are laws banning obscenity, see, e.g., Miller v. California, 413 U.S. 15 (1973), laws prohibiting the advocacy of violent overthrow of government, see, e.g., Dennis v. United States, 341 U.S. 494 (1951), laws forbidding the display of "For Sale" signs in front of houses, see, e.g., Linmark Assocs., Inc. v. Township of Willingboro, 431 U.S. 85 (1977), and laws or injunctions prohibiting the disclosure or publication of certain specified sorts of information, see, e.g., Landmark Communications, Inc. v. Virginia, 435 U.S. 829 (1978); New York Times Co. v. United States, 403 U.S. 713 (1971).

A second form of content-based restriction involves government action that appears on 
In its interpretation of the first amendment, the Supreme Court has been especially wary of government action that restricts speech because of its content. ${ }^{4}$ The Court has, to be sure, permitted content-based restrictions when the speech at issue has fallen within one of those special and limited categories of expression, such as obscenity, false statements of fact, or fighting words, that the Court has found to be of such low value in terms of the historical, philosophical, and political purposes of the amendment as to be entitled to less than full constitutional protection. ${ }^{5}$ Outside this "low value" realm, however, the Court has embraced a stringently speechprotective set of standards, sustaining content-based restrictions of "fully protected" expression in only the most extraordinary circumstances. ${ }^{6}$

its face to be content-neutral, but that is directed at a harm caused by the content of the speech. See Ely, supra note 1, at 1496-502; Nimmer, The Meaning of Symbolic Speech Under the First Amendment, 21 U.C.L.A. L. REv. 29, 53-54 (1973). For examples of this sort of content-based restriction, see Tinker v. Des Moines School Dist., 393 U.S. 503 (1969) (striking down school's prohibition on wearing black armbands); Feiner v. New York, 340 U.S. 315 (1951) (upholding disorderly conduct conviction because of crowd's reaction to speaker's controversial statement). This sort of law must be viewed as content-based because the restriction is triggered by the content of the communication. Such laws thus seem to pose a threat to the values underlying the first amendment similar to that posed by the more common form of content-based restriction.

Finally, a content-based restriction arguably exists when a law that is content-neutral on its face can be shown to have been motivated by governmental hostility towards speech of a certain content. On the question of improper motivation generally, see L. TRIBE, supra note 1, §§ 12-5 to -6; Brest, Palmer v. Thompson: An Approach to the Problem of Unconstitutional Legislative Motive, 1971 Sup. CT. REv. 95; Ely, Legislative and Administrative Motivation in Constitutional Law, 79 YALE L.J. 1205 (1970). Further aspects of the contentbased/content-neutral distinction are discussed in the text at notes 97-125 infra.

' See, e.g., Hudgens v. NLRB, 424 U.S. 507, 520 (1976); Police Dep't v. Mosley, 408 U.S. 92, 95 (1972). See also City of Madison, Joint School Dist. No. 8 v. Wisconsin Employment Relations Comm'n, 429 U.S. 167, 175-76 (1976).

s The "two-level" theory of speech originated in Chaplinsky v. New Hampshire, 315 U.S. 568 (1942). See Kalven, The Metaphysics of the Law of Obscenity, 1960 Sup. Cr. REv. 1. From the 1940 s to the mid-1960s, the Court viewed "low value" speech as wholly unprotected by the first amendment. More recently, however, the Court has tended to treat "low value" speech in a more speech-protective manner. Although not abandoning the "two-level" theory entirely, the Court's more flexible approach has at least reduced its importance. Compare, e.g., Valentine v. Chrestensen, 316 U.S. 52 (1942) with Virginia State Bd. of Pharmacy v. Virginia Citizens Consumer Council, Inc., 425 U.S. 748 (1976); Beauharnais v. Illinois, 343 U.S. 250 (1952) with New York Times Co. v. Sullivan, 376 U.S. 254 (1964); Chaplinsky v. New Hampshire, 315 U.S. 568 (1942) with Cohen v. California, 4133 U.S. 15 (1971). See generally L. TriBE, supra note 1, $\S 12-17$; Karst, Equality as a Central Principle of the First Amendment, 43 U. CHI. L. REv. 20, 30-34 (1975). The Court's analysis of the obscenity issue has not as yet followed this pattern. See, e.g., Miller v. California, 413 U.S. 15 (1973); Roth v. United States, 354 U.S. 476 (1957).

- The Court has not articulated a single, all-embracing standard, but rather it has employed several different standards and approaches, including categorization, clear and present danger, and variations of the compelling-interest test. See, e.g., Nebraska Press Ass'n 
One sequence of cases does not conform to this description of the Court's treatment of content-based restrictions of "fully protected" speech. Although presenting widely varying fact patterns, these cases have each involved a content-based restriction defined in terms of expression about an entire subject, rather than in terms of a particular viewpoint, idea, or item of information. That is, the restrictions in these cases accorded disfavored treatment to "fully protected" speech because the speech related to such general subject matters as public affairs, sex, or partisan politics. ${ }^{7}$ The question posed by these cases is whether the stringent standards of review employed by the Court to test content-based restrictions generally should be used to test these sorts of content-based restrictions as well.

This question is not an easy one, for although "subject-matter" distinctions unquestionably regulate content, they at least appear to do so in a viewpoint-neutral manner. ${ }^{8}$ As a consequence, such restrictions do not fit neatly within the Court's general framework for reviewing laws regulating speech; it is unclear whether they should be treated as content-based, content-neutral, or something altogether different. Not surprisingly, then, the Court has encountered considerable difficulty in attempting to make sense of these cases. Not only has the Court's reasoning lacked analytical clarity and consistency, but the results reached in individual cases often seem questionable and the implications for first amendment doc-

v. Stuart, 427 U.S. 539 (1976); Police Dep't v. Mosley, 408 U.S. 92 (1972); Cohen v. California, 403 U.S. 15 (1971); Brandenburg v. Ohio, 395 U.S. 444 (1969). In the past quarter-century, the Court has actually upheld such restrictions in only a handful of decisions. Interestingly, almost all of these decisions have appeared in the past ten years. See, e.g., Parker v. Levy, 417 U.S. 733 (1974). See also FCC v. Pacifica Foundation, 98 S.Ct. 3026 (1978); Zaccihini v. Scripps-Howard Broadcasting Co., 433 U.S. 562 (1977); Jones v. North Carolina Prisoners' Labor Union, 433 U.S. 119 (1977). I have not included in this list the "subject-matter" cases that are the focus of this article. In the period before the last quarter-century, decisions upholding content-based restrictions were somewhat less rare. See, e.g., Feiner v. New York, 340 U.S. 315 (1951); Whitney v. California, 274 U.S. 357 (1927); Schenck v. United States, 249 U.S. 47 (1919).

"I am concerned in this article with only those cases in which "fully protected" speech is disadvantaged because of its subject matter. A subject-matter classification according disadvantageous treatment to "less than fully protected" speech poses a different problem, for the inquiry in such cases centers on the "value" of the speech restricted. That appears not to be the central inquiry in the subject-matter cases examined in this article. This is not to say, however, that my analysis of these cases has no implications for the Court's two-level theory.

Subject-matter distinctions are not the only content-based restrictions that appear to be viewpoint-neutral. See, e.g., FCC v. Pacifica Foundation, 98 S.Ct. 3026 (1978) (broadcast restrictions on use of obscene, indecent, or profane language); Cohen v. California, 403 U.S. 15 (1971) (restriction on offensive language). Much of what is said in this article about subject-matter restrictions is applicable to other viewpoint-neutral restrictions as well. 
trine highly disquieting. This article explores the Court's handling of this question and then offers an analysis designed to place the question in a more manageable context. It is hoped that this analysis will help solve the subject-matter puzzle and at the same time shed some light on first amendment doctrine generally.

\section{The Supreme Court and Subject-Matter Restrictions: Decisions in Search of Doctrines}

\section{A. The Problem}

In Rowan v. United States Post Office Department, ${ }^{9}$ one of the Court's first encounters with a subject-matter distinction, ${ }^{10}$ the Court considered the constitutionality of a federal statute designed to enable householders to prevent the delivery of unwanted mail. The statute directed the Postmaster General, upon request of a householder, to issue an order directing the offending sender to refrain from any further mailings to that householder. There can be little doubt that such legislation promotes a legitimate and substantial interest and would, if drafted in a content-neutral manner, withstand ordinary content-neutral scrutiny. ${ }^{11}$ The statute at issue in Rowan, however, was not content-neutral. Rather, it was directed at only those mailings that were "offensive because of their lewd and salacious character"12 and could be brought into play only if the householder found the initial mailing to be "erotically arousing or sexually provocative." 13 On its face, then, the statute permitted speech to be restricted only if it related to sex; speech relating to other subjects such as politics or religion, even if equally offensive,

' 397 U.S. 728 (1970).

10 Although Rowan was not the first case to pose the subject-matter problem, the Court in most earlier cases found it unnecessary to address this issue, for it was able to hold the legislation invalid on other grounds. See, e.g., Cox v. Louisiana, 379 U.S. 536 (1965) (disturbing-the-peace statute held unconstitutionally vague); Thomas v. Collins, 323 U.S. 516 (1945) (requirement to register before soliciting union memberships invalid as prior restraint). In at least two pre-Rowan cases, the Court upheld legislation creating subject-matter classifications without addressing the subject-matter question. See Red Lion Broadcasting Co. v. FCC, 395 U.S. 367 (1969); United Pub. Workers v. Mitchell, 330 U.S. 75 (1947). Similarly, in two recent cases involving subject-matter classifications, the Court in each case held the legislation at issue unconstitutional on other grounds. See First Nat'l Bank v. Bellotti, 435 U.S. 765 (1978); City of Madison, Joint School Dist. No. 8 v. Wisconsin Employment Relations Comm'n, 429 U.S. 167 (1976). In these cases, the Court seems to have focused primarily on the "discrimination against types of speakers" issue rather than on the content issue as such.

"See Stone, Fora Americana: Speech in Public Places, 1974 Sup. Ct. Rev. 233, 262-66. See also Rowan v. United States Post Office Dep't, 397 U.S. at 736-38.

12397 US. at 731.

ts 39 U.S.C. $\$ 3008(a)(1976)$. 
was simply outside the scope of the statutory scheme. ${ }^{14}$ The natural question for the Court should have been whether the statute in Rowan was permissible given the stringent standards ordinarily applied to content-based restrictions. Had the statute been limited in application only to antiwar or antiblack mailings, it would almost surely have triggered the most rigorous standards of first amendment scrutiny. In Rowan, however, the Court upheld the statute without even mentioning this issue. The Court simply ignored the subject-matter distinction, treating the statute as if it were in fact content-neutral..$^{15}$

This treatment is all the more striking in light of the Court's concern about this issue in a different aspect of the case. Throughout its opinion, the Court emphasized that the statute granted the householder complete and unreviewable authority to decide for himself whether a mailing was "erotically arousing or sexually provocative." This grant of individual discretion was "essential," the Court observed, in order "to avoid possible constitutional questions that might arise from vesting the power to make any discretionary evaluation of the material in a governmental official."16 Thus, although the unequivocal governmental decision to accord disfavored treatment to speech relating to sex passed unnoticed, the Court evinced real concern over the possibility that the government might treat some sexually-related speech differently from other sexually-related speech. The Court did not explain why one form of content-based restriction should be treated any differently from the other. ${ }^{17}$

"The statute at issue in Rowan is in fact only a quasi-subject-matter restriction, for although it limits speech only if it relates to sex, it does not restrict all speech on that subject. Despite this duality, the Rowan statute nevertheless possesses the most important characteristics of subject-matter restrictions.

is It is of course possible that Rowan was premised upon an unstated assumption that nonobscene, sexually offensive speech is entitled to less than "full" first amendment protection. The Court has since rejected this classification of such speech, however. See Young v. American Mini Theatres, Inc., 427 U.S. 50, 73 n.1 (1976) (Powell, J., concurring); id. at 8487 (Stewart, J., dissenting).

" 397 U.S. at 757.

"One final wrinkle clouds Rowan still further. If the householder has absolute discretion to decide whether a mailing is "erotically arousing or sexually provocative," then he can, as the Court itself recognized, prohibit the delivery of even " $a$ dry goods catalogue because he object to the contents." 397 U.S. at 737. See also id. at 741 (Brennan, J., concurring). The subject-matter distinction, in other words, exists in form only. In operation, the statute may well be content-neutral. The Court might thus have seen the subject-matter distinction as wholly unimportant. This is, however, too simple. A householder seeking to use the statute to ban the delivery of offensive but nonsexually related speech would have to lie, since, to bring the statute into play he would have to inform the Postmaster General that the mailing was "erotically arousing or sexually provocative." Even though he could not be held legally accountable for this dishonesty, the very need for such deceit would unquestionably deter such use of the statute. In short, the statute will likely have a differential impact, leaving 
The Court's failure to examine closely the statute in Rowan contrasts sharply with its direct focus on the subject-matter issue two years later in Police Department $v$. Mosley. ${ }^{18}$ Mosley concerned the constitutionality of a Chicago ordinance making it unlawful for any person to picket or demonstrate on a public way within 150 feet of a school building while the school was in session. The ordinance was not content-neutral, however, for it expressly exempted "peaceful picketing of any school involved in a labor dispute" from its otherwise absolute prohibition. As the Court recognized, the ordinance embodied a clear subject-matter distinction: "Peaceful picketing on the subject of a school's labor-management dispute is permitted, but all other peaceful picketing is prohibited." ${ }^{19}$ Indeed, the Court found that " $[t]$ he central problem with Chicago's ordinance is that it describes permissible picketing in terms of its subject matter." ${ }^{20}$ Such restrictions are presumptively invalid, the Court declared, for "above all else" the first amendment is directed against government efforts "to restrict expression because of its message, its ideas, its subject matter, or its content." 21 In effect, then, the Court in Mosley proceeded on the assumption that subject-matter restrictions are to be treated no differently from other sorts of content-based restrictions.

Chicago had defended its ordinance as necessary to prevent disruption of school activities. Although conceding that cities may have a substantial interest in prohibiting picketing that disrupts a

the subject-matter issue in Rowan unresolved.

It should also be noted that the Rowan statute involved two content-based restrictions in addition to the one discussed in the text. First, the householder will himself make contentbased decisions in deciding which mailing to ban, and the government, through the statutory scheme, will enforce these content-based decisions. Governmental enforcement of private "censorship," although ordinarily prohibited, might be permissible here because in this situation the householder's privacy interest can be protected without interfering with the mailer's ability to communicate with willing recipients. See Stone, supra note 11, at 262-66. Second, the Rowan statute could be brought into play only if the initial mailing was an advertisement that offered for sale matter the householder found to be "erotically arousing or sexually provocative." The Court itself paid no attention to the statute's focus on advertisements. Even though "commercial speech" was still "unprotected" at the time of this decision, the result in Rowan could not have been predicated upon that doctrine. This is so for two reasons: (1) the commercial speech involved consisted of advertisements for matters that were themselves protected by the first amendment, cf. New York Times Co. v. Sullivan, 376 U.S. 254 (1964) (not all forms of commercial speech are unprotected), (2) the statute looked to content to classify advertisements for mítter protected by the first amendment. Even in 1970, a law restricting advertisements for antiwar books, for example, would not have been viewed as falling within the "commercial speech" doctrine.

"* 408 U.S. 92 (1972).

"Id. at 95.

20 Id.

2 Id. See also id. at $98,99$. 
school, the Court noted that "Chicago itself has determined that peaceful labor picketing during school hours is not an undue interference with school," 22 and that "however the term 'peaceful' is defined," peaceful nonlabor picketing "is obviously no more disruptive than "peaceful' labor picketing." ${ }^{23}$ Chicago had argued further, however, that the subject-matter classification was justified because "as a class, nonlabor picketing is more prone to produce violence than labor picketing." ${ }^{24}$ But the Court was again unpersuaded, emphasizing that "[p]redictions about imminent disruption from picketing involve judgments appropriately made on an individualized basis, not by means of broad classifications, especially those based on subject matter." 25 Whatever excesses may arise out of nonlabor picketing can, as with labor picketing, "be controlled by narrowly drawn statutes,' . . . focusing on the abuses and dealing even-handedly with picketing regardless of subject matter." ${ }_{26}$ The Court thus held the ordinance invalid "because it makes an impermissible distinction between labor picketing and other peaceful picketing." 27

It seems evident that, tested against the Mosley standards, the statute upheld in Rowan could not pass constitutional muster. Although sexually-related mail is arguably more likely to be more offensive to more householders than nonsexually-related mail, judgments about the offensiveness of the materials, at least according to Mosley, should not be made "by means of broad classifications, especially those based on subject matter." 28 If the government

2 Id. at 100 .

23 Id.

2Id.

${ }^{2 s}$ Id. at $100-01$.

2* Id. at 102.

${ }^{27}$ Id. at 94. It should be noted that the Court in Mosley employed an important but previously little-used doctrine. Ordinarily, in testing the constitutionality of content-based restrictions, the Court focuses primarily on whether the restricted speech is sufficiently harmful to important state interests to warrant the restriction. In Mosley, however, the Court emphasized the difference in treatment between labor and nonlabor speech and focused on whether the distinction itself was justified. The Court looked not to the harmfulness of the nonlabor speech as such, but to the relative harmfulness of labor and nonlabor speech. The issue, in other words, was cast in equal protection as well as first amendment terms. This supplemental equal protection analysis is of special utility in examining underinclusive content-based restrictions, such as those in which the government adopts a content-based restriction in lieu of a broader, content-neutral restriction. An obvious example of such a restriction, in addition to the statutes in Rowan and Mosley, would be a law prohibiting Democrats from using loudspeakers at night in residential neighborhoods. The Mosley doctrine asks not whether there is adequate reason to restrict the speech restricted, but whether there is adequate reason to restrict only the speech restricted. A negative answer to the second question eliminates the need even to ask the first.

$2 \pi 408$ U.S. at 100-01. 
wished to protect the householder, it should have done so in such a way as to deal "even-handedly" with all potentially offensive mail "regardless of subject matter." Mosley and Rowan thus seem fundamentally at odds in their treatment of subject-matter distinctions.

\section{B. Treatment of Subject-Matter Restrictions after Mosley}

Over the next five years, the Court confronted subject-matter restrictions in varying forms and contexts. Following the pattern set in Rowan and Mosley, the Court in the ensuing decisions failed to recognize the relationship between the cases or the special problem posed by subject-matter restrictions.

1. CBS v. Democratic National Committee. In the term following Mosley, CBS v. Democratic National Committe ${ }^{2 \theta}$ posed the question whether radio and television broadcasters could, with FCC approval, constitutionally refuse to sell advertising time to groups or individuals seeking to express their views on controversial issues of public importance. The case raised two basic issues. First, by analogy to traditional public forum analysis, which guarantees an individual the right to use various sorts of government-owned property for speech purposes, is there a "public forum" right of the individual to use the "public" airwaves for purposes of expression? The public forum doctrine is in essence a species of content-neutral analysis, and its contours are thus defined through a form of balancing. ${ }^{30}$ Second, even if there is no public forum right as such, is the challenged policy, given the willingness of broadcasters routinely to sell airtime for commercial advertising, an impermissible regulation of content? The court of appeals, in a controversial decision, directed its attention primarily to the second issue. Although stating that subject-matter distinctions, such as the commercial/publicissue distinction involved in $C B S$, were 'somewhat less 'odious' than ... discrimination[s] among different controversial viewpoints on particular issues," the court nevertheless held the challenged policy invalid as an unconstitutional "discrimination among speakers . . . based on what they intend to say." 31

The Supreme Court reversed. In so doing, however, the Court

20412 U.S. 94 (1973).

${ }^{30}$ See generally L. TRIBE, supra note 1 , at $\S 12-21$; Kalven, The Concept of the Public Forum: Cox v. Louisiana, 1965 Sup. CT. REv. 1; Stone, supra note 11.

II Business Executives' Move for Vietnam Peace v. FCC, 450 F.2d 642, 660, 661 (D.C. Cir. 1971), rev'd sub nom., CBS v. Democratic Nat'l Comm., 412 U.S. 94 (1973). CBS also raised the question whether the challenged policy constituted government action that would trigger the demands of the first amendment. The Court as a whole did not decide this question. 
paid scant attention to the subject-matter issue. Rather, Chief Justice Burger, speaking for the Court, focused primarily on the public forum issue, explaining at some length that to require broadcasters to air public-issue advertising would intrude upon their journalistic discretion, endanger effective operation of the fairness doctrine, create serious administrative problems, and result in greater governmental supervision of broadcasters. ${ }^{32}$ Only at the very end of his opinion did Chief Justice Burger take note of the subjectmatter issue. Mosley provided "little guidance" in $C B S,{ }^{33}$ Chief Justice Burger argued, because the faimess doctrine independently required broadcasters to provide full and fair coverage of public issues. Accordingly, the only real difference in treatment between commercial and public-issue speech was that with respect to the latter, broadcasters, rather than advertisers, would "determine what issues are to be discussed by whom, and when." 34 This difference, he concluded, did not amount to " 'discrimination' against" public issue speech. ${ }^{35}$

The Chief Justice's analysis of the subject-matter issue is unsatisfying at best. The operation of the fairness doctrine may lessen the differential impact of the challenged policy, but it surely does not eliminate it. As Justice Brennan demonstrated in dissent, the power to "determine what issues are to be discussed by whom, and when" is of no small import, ${ }^{36}$ and Chief Justice Burger's conclusion that "there is no 'discrimination' against controversial speech" in $C B S$ seems simply to blink reality. ${ }^{37}$ The real explanation for the decision, I submit, was the Court's lack of concern with the particular content-based restriction at issue. It is inconceivable that the Court would find "no discrimination" if broadcasters, with FCC approval, routinely sold airtime to all commercial and public-issue advertisers except Socialists, whose views were presented instead through a form of fairness doctrine under the journalistic control of broadcasters. Even in the context of broadcasting, ${ }^{38}$ the Court would

32412 U.S. at 123-27.

Id. at 129 .

अ Id. at 130 .

${ }^{35}$ Id.

36 See id. at 184-96 (Brennan, J, dissenting).

s] Id. at 130.

38 As recognized in CBS, the Court has long taken the position that "the broadcast media pose unique and special problems not present in the traditional free speech case." 412 U.S. at 101. See also FCC v. Pacifica Foundation, 98 S.Ct. 3026, 3039-41 (1978); FCC v. National Citizens Comm. for Broadcasting, 436 U.S. 775, 798-99 (1978); Red Lion Broadcasting Co. v. FCC, 395 U.S. 367, 388-90 (1969). Although this doctrine played a role in the Court's evaluation of the "public forum" issue in CBS, Chief Justice Burger did not expressly rely upon it in his analysis of the subject-matter issue. 
undoubtedly demand at the very least a compelling justification for the content-based restriction. The Court's failure in $C B S$ even to examine the justifications, if any, for the differential treatment of commercial and public-issue speech suggests that it found the distinction between these two types of speech less threatening from the standpoint of the policies underlying the first amendment than the distinction in the hypothetical case. Regrettably, the Court made no serious effort to explain or to justify this reaction, or to reconcile it with Mosley's ${ }^{39}$ assimilation of subject-matter restrictions to other content-based restrictions.

2. Lehman v. City of Shaker Heights. Mosley fared no better when the Court again confronted the commercial/public issue distinction a year later in Lehman $v$. City of Shaker Heights. ${ }^{40}$ In Lehman, a sharply divided Court upheld the constitutionality of the city's policy permitting the interior advertising spaces of its transit vehicles to be leased for the display of commercial but not publicissue or political messages. Lehman, like $C B S$, posed both the content-neutral public forum and the content-based subject-matter issues. Unfortunately, Justice Blackmun, speaking in a plurality opinion for four members of the Court, blurred these two issues. With respect to the subject-matter issue, however, Justice Blackmun made it clear that the distinction between commercial and public-issue speech would be permissible so long as it was not "arbitrary, capricious, or invidious." 41 Pointing to the city's interests in protecting a "captive audience" from potentially offensive public-issue advertisements and avoiding the "sticky administrative problems" that might arise if such advertisements were accepted for display, Justice Blackmun concluded that the challenged policy easily satisfied this standard.

The standard adopted by Justice Blackmun is a far cry from the stringent standards ordinarily employed by the Court to test content-based restrictions and applied in Mosley to a restriction similarly linked to subject matter. ${ }^{42}$ Justice Blackmun offered two basic arguments that may be viewed as explanations for his use of this extraordinarily lenient standard of review. First, he emphasized that in its operation of the transit system and its sale of advertising

33 In his dissenting opinion, Justice Brennan found the policy invalid on public forum grounds. He thus referred to the subject-matter issue only briefly, relying specifically on Mosley as controlling authority. See 412 U.S. at 200-01 (Brennan, J., dissenting).

10418 U.S. 298 (1974). For a more extensive analysis of Lehman, see Stone, supra note 11.

" 418 U.S. at 303.

12 See note 6 supra. 
space "the city is engaged in commerce." 43 The Court has long recognized, however, that whatever significance the proprietary/ governmental distinction may have for other purposes, it is ordinarily irrelevant to the standards imposed under the Constitution. ${ }^{44}$ Indeed, less than a year after Lehman, the Court, in an opinion written by Justice Blackmun, implicitly rejected the notion that the proprietary character of government action alters the appropriate standards of first amendment analysis. ${ }^{45}$ Moreover, it seems doubtful at best that Justice Blackmun would apply his "arbitrary, capricious, or invidious" standard if the city, acting in its proprietary capacity, had chosen instead specifically to exclude Communist, sexist or antiwar messages from its vehicles. ${ }^{46} \mathrm{I}$ therefore suspect that Justice Blackmun was moved in Lehman less by any concern that "the city is engaged in commerce" than, like Chief Justice Burger in $C B S$, by the special nature of the content-based restriction involved.

This suspicion is confirmed by Justice Blackmun's second asserted justification for his lenient standard of review. Justice Blackmun emphasized that "the city has decided that '[p]urveyors of goods and services saleable in commerce may purchase advertising space on an equal basis, whether they be house builders or butchers." "47 The point seems to be that since all those seeking to purchase advertising space for commercial purposes are treated alike, and all those seeking to purchase space for public issue or political purposes are treated alike, the content problem virtually disappears. The same argument, however, could be made with respect to any content-based restrictions, for any such restriction treats all those subject to its provisions equally, as it does those not subject to its provisions. In analyzing such restrictions, the Court ordinarily focuses not only on whether all those within the classes defined by the state are treated equally, but also on whether the content classification itself is permissible. Thus, Justice Blackmun's observation

4318 U.S. at 303.

" See, e.g., City of Trenton v. New Jersey, 262 U.S. 182, $191-92$ (1923); City of St. Petersburg v. Alsup, 238 F.2d 830, 831-32 (5th Cir. 1956); Lawrence v. Hancock, 76 F. Supp. 1004, 1008 (S.D.W. Va. 1948). But see Hughes v. Alexandria Scrap Corp., 426 U.S. 794 (1976). See also Gilmore v. City of Montgomery, 417 U.S. 556 (1974); Burton v. Wilmington Parking Auth., 365 U.S. 715 (1961).

is Southeastern Promotions, Ltd. v. Conrad, 420 U.S. 546 (1975). See Karst, supra note 5 , at 35 .

" But cf. Buck v. Impeach Nixon Comm., 498 F.2d 37 (7th Cir. 1974) (transit authority enjoined from denying advertising space to impeachment posters).

47418 U.S. at 303.04 (quoting Lehman v. City of Shaker Heights, 34 Ohio St. 2d 143, 146, 296 N.E.2d 683, 685 (1973)). 
makes sense as a justification of the use of a particularly lenient standard of review only if it is premised upon the assumption that the commercial/public-issue classification at issue in Lehman is in some fundamental sense different and less disturbing than most other content-based distinctions. Yet, like Chief Justice Burger in $C B S$, Justice Blackmun made no effort to explain this assumption or to square it with Mosley.

Justice Douglas, who cast the crucial fifth and deciding vote in Lehman, concurred with Justice Blackmun's disposition of the case, but reached this result for his own, quite distinct, reasons. Unlike Justice Blackmun, Justice Douglas concluded that the display of any advertisement, regardless of content, in a publicly-owned vehicle would violate the constitutional rights of "captive" commuters. On this view of the case, the subject-matter issue falls by the wayside, for the Constitution clearly does not require a state that has engaged in one unconstitutional act to adopt another simply for the sake of equality. ${ }^{48}$ As if to highlight his disagreement with Justice Blackmun, however, Justice Douglas went out of his way to note that he did "not view the content of the message as relevant either to petitioner's right to express it or to the commuters' right to be free from it." ${ }^{\prime 9}$ Thus, Justice Douglas seemed clearly, if unnecessarily, to indicate a preference for the Mosley approach to subjectmatter distinctions.

Justice Brennan, speaking for the four dissenters in Lehman, maintained that when "the discrimination is among entire classes of ideas, rather than among points of view within a particular class," it does not become "any less odious." 50 According to Justice Brennan, since commercial advertisements frequently carry implicit "political" messages, the city's policy opened the door to sub rosa discrimination among differing viewpoints on political issues. ${ }^{51}$ Thus, building upon Mosley, but ignoring $C B S$, Justice Brennan declared that the subject-matter restriction in Lehman should properly be tested against the stringent standards of review used to test content-based restrictions generally. Applying those standards, Justice Brennan concluded that "the city's selective exclusion of political advertising constitutes an invidious discrimination on the basis of subject matter, in violation of the First and Fourteenth Amendments." 52

43 But cf. Dothard v. Rawlinson, 433 U.S. 321 (1977) (sex discrimination in hiring prison guards justified because of inhumane and unconstitutional conditions in the prison).

- 418 U.S. at 308 (Douglas, J., concurring).

Id. at 316 (Brennan, J., dissenting).

s1 See id. at 317-18.

32 Id. at 319-20. 
3. Erznoznik v. City of Jacksonville. In Erznoznik $v$. City of Jacksonville, ${ }^{53}$ decided in 1975 , the Court considered the constitutionality of a subject-matter restriction that, as in Rowan, limited expression because of its concern with sex. The Court held invalid an ordinance prohibiting a drive-in movie theater from displaying any film containing nudity if the theater's screen was visible from a public street or place. In defense of this ordinance, the city had argued that it was entitled to protect its citizens against unwilling exposure to offensive expression, and that films containing nudity were likely to be "especially offensive to passersby."54 The Court rejected this argument, emphasizing that "when the government . . . undertakes selectively to shield the public from some kinds of speech on the ground that they are more offensive than others, the First Amendment strictly limits its power." ${ }^{55}$ Applying a strict standard of justification, the Court concluded that "the limited privacy interest of persons on the public streets cannot justify this censorship of otherwise protected speech on the basis of its content." ${ }^{66}$ The state interest, in other words, was not of sufficient importance to justify a content-based restriction. The Court distinguished Rowan and Lehman - the only prior decisions upholding content-based restrictions on a captive audience rationale-on the ground that the degree and nature of the captivity were more serious in those cases than in Erznoznik. Although most likely a persuasive distinction at the factual level, this response to Rowan and Lehman is hardly satisfactory from the standpoint of doctrine. For there can be no doubt that, in testing the constitutionality of the subject-matter distinctions, the Court embraced a stricter standard in Erznoznik than in either of the earlier cases.

Erznoznik's disharmony with Rowan and the plurality opinion in Lehman becomes even clearer upon considering the Court's treatment of the city's further argument that the ordinance was justified because the display of nudity on a drive-in movie screen would distract motorists and cause accidents. Echoing Mosley, the Court indicated that the standards used to test classifications based on "the subject matter of expression" should be no different from those used to test content-based restrictions generally. ${ }^{57}$ Focusing on the content distinction itself rather than on the strength of the state interest, the Court dismissed the city's argument out-of-hand. The

\footnotetext{
ss 422 U.S. 205 (1975).

st Id. at 208.

ss Id. at 209.

s Id. at 212.

st See id. at 215.
} 
ordinance, given the asserted purpose, was "strikingly underinclusive." "Th "There is no reason to think," the Court explained, "that a wide variety of other scenes in the customary screen diet . . . would be any less distracting to the passing motorist." ${ }^{59}$ Had the Court employed a similar underinclusiveness analysis in Rowan and Lehman, as well as in CBS, it would almost surely have held the restrictions challenged there invalid. Thus, while lending force to Mosley's approach to subject-matter restrictions, Erznoznik at the same time obscured the issue further. ${ }^{80}$

4. Greer v. Spock. It was in this context that, in the term following Erznoznik, the Court decided Greer $v$. Spock, ${ }^{61}$ which involved a subject-matter restriction directed specifically at partisan political speech. The Court had, even before Greer, several opportunities to consider similar sorts of restrictions. In United States Civil Service Commission v. National Association of Letter Carriers ${ }^{62}$ and its companion case, Broadrick v. Oklahoma, ${ }^{63}$ the Court, shortly after its 1973 decision in $C B S$, considered the constitutionality of federal and state statutes that, among other things, prohibited public employees from expressing their views "on public affairs, personalities and matters of public interest" if the expression is directed "toward party success." nature of the restriction in depth, the Court declined in these cases to invalidate such legislation on grounds of overbreadth. The Court reasoned that since the restrictions "are not aimed at particular parties, groups, or points of view, but apply equally to all partisan activities of the type described," 65 they should be subjected "to a less exacting . . . scrutiny." 68 Similarly, in its 1976 decision in Buckley $v$. Valeo, ${ }^{67}$ which involved the validity of various aspects of the Federal Elections Campaign Act, the Court observed that "the Act does not focus on the ideas expressed by persons or groups subject to its regulations." 68 Because of this viewpoint neutrality,

38 Id. at 214.

ss Id. at 214-15.

- The dissenters, Chief Justice Burger and Justices Rehnquist and White, made only passing reference to the subject-matter issue. See e.g., 422 U.S. at 223 (Burger, C.J., dissenting).

1124 U.S. 828 (1976).

2413 U.S. 548 (1973).

413 U.S, 601 (1973).

a United Pub. Workers v. Mitchell, 330 U.S. 75, 100 (1947), quoted in United States Civil Serv. Comm. v. National Ass'n of Letter Carriers, 413 U.S. 548, 556 (1973).

es United States Civil Serv. Comm. v. National Ass'n of Letter Carriers, 413 U.S. at 564.

" Broadrick v. Oklahoma, 413 U.S, at 616.

n 424 U.S. 1 (1976).

as Id. at 17. See also id. at 39. The Act involved a subject-matter distinction, however, because it regulated various constitutionally protected activities, such as the making of 
the Court treated the restriction as if it were content neutral. ${ }^{69}$ As in Letter Carriers and Broadrick, it simply ignored the subjectmatter distinction.

Greer concerned the asserted right of political candidates to enter ordinarily unrestricted areas of the Fort Dix Military Reservation in order to distribute literature and discuss their campaigns with soldiers stationed at the base. Although the base routinely permitted civilian speakers to address military personnel on subjects ranging from business management to drug abuse, ${ }^{70}$ it prohibited by regulation any speech or demonstration of a partisan political nature. The candidates challenged this regulation as an impermissible restriction on access to a public forum and, also, as an impermissible restriction on content. After rejecting the public forum claim, ${ }^{71}$ Justice Stewart, speaking for the Court, turned his attention-briefly-to the content issue. Emphasizing that "there is no claim that the military authorities discriminated in any way among candidates for public office based upon the candidates' supposed political views,"72 and that the ban on partisan political speech "is wholly consistent with the American constitutional tradition of a politically neutral military,"73 Justice Stewart concluded that the regulation was not an unconstitutional restriction on the basis of content.

In reaching this conclusion, Justice Stewart seems to have embraced the view that when government regulates expression on its own property in a nonpublic forum context, it should be granted a freer hand to draw lines according to content than it would have in other circumstances. ${ }^{74}$ Although this principle lacks clear roots in prior first amendment jurisprudence, Justice Stewart made no effort to explain or to defend it. $^{75}$ More important for our purposes,

financial contributions for "speech" purposes, only in the context of partisan political "speech."

"See id. at $16-19 ; 60-84$.

70 In addition, visiting clergymen were occasionally invited to participate in religious services at the base chapel, and various theatrical and musical productions were presented on the base. See 424 U.S. at 831.

"Justice Stewart's analysis of the public forum issue focused almost exclusively on whether the property had traditionally been considered a public forum, rather then on whether the prohibited speech would be incompatible with the normal function of the property. It thus seems at variance with developing public forum principles. See The Supreme Court, 1975 Term, 90 HARv. L. REv. 56, 152-59 (1976). See generally Stone, supra note 11.

72424 U.S. at 838.39.

73 Id. at 839 .

"See id. at 838 n.10.

75 One glaring difficulty with this approach is that it requires the Court to determine at what point government's decision to allow speech of some content on its property converts a 
he did not make clear whether this principle is applicable to all content-based restrictions or, rather, whether it is applicable only when, as in Greer, the restriction is defined in a viewpoint-neutral manner in terms of subject matter. Although the tenor of the opinion would seem to support the latter interpretation, ${ }^{76}$ Greer has since been cited by the Court for the former proposition. ${ }^{77}$ Thus, the extent to which the Court was influenced by the subject-matter character of the contested regulation remains unclear. What is clear is that, whatever his rationale, Justice Stewart made no mention in Greer either of Letter Carriers, Broadrick, and Buckley, in which similar restrictions had been viewed as content neutral, or of Mosley and Erznoznik, in which subject-matter restrictions had been treated as content based. ${ }^{78}$

5. Young v. American Mini Theatres, Inc. Finally, Young $v$. American Mini Theatres Inc. ${ }^{79}$ also decided in 1976, once again posed the problem of subject-matter restrictions relating to sex. Young concerned the constitutionality of a series of Detroit zoning ordinances that required motion picture theaters exhibiting nonobscene but sexually-explicit movies to be dispersed throughout the city. ${ }^{80}$ The city had enacted the ordinances on the theory that the location of several such theaters or other "regulated" businesses in the same neighborhood leads ultimately to deterioration of the community. The Court, in a five-to-four decision, upheld the ordinances. Justice Stevens, speaking for four members of the Court, ${ }^{81}$ recognized that the ordinances involved a clear content-based distinction, but nevertheless adopted a markedly lenient standard of

nonpublic forum into a public forum. Justice Stewart does not explain why such a conversion took place in Lehman, where he joined the Brennan dissent, but not in Greer.

7 Justice Stewart noted repeatedly that the regulation was viewpoint neutral, see 424 U.S. at 838-39, and referred specifically to the subject-matter concept, see id. at 838 n.10. Professor Tribe has adopted this interpretation of Greer. See L. TrIBE, supra note 1, § 12-21, at $691 \mathrm{n} .21,692$.

$\pi$ See Jones v. North Carolina Prisoners' Labor Union, 433 U.S. 119, 133-34 (1977).

${ }^{73}$ In a separate concurring opinion, Justice Powell, while invoking Letter Carriers, treated the regulation as if it were content neutral, and strongly suggested a distinction between subject-matter restrictions and other content-based restrictions. See 424 U.S. at 84344, 848 n.3. In his dissenting opinion, Justice Brennan, joined by Justice Marshall, focused primarily on the public forum issue. He indicated in passing, however, that the regulation was also invalid because it embodied an impermissible regulation of content. See id. at 863 , 867.

7. 427 U.S. 50 (1976).

* The ordinances governed the location of any theater used to present "material distinguished or characterized by an emphasis on matter depicting, describing, or relating to 'Specified Sexual Activities' or 'Specified Anatomical Areas.' " Id. at 50.

${ }^{81}$ Although Justice Powell joined some parts of the Stevens opinion, he did not join that part involving the issues here under discussion. 
justification. "It is not our function," he declared, "to appraise the wisdom of [the city's] decision to require adult theaters to be separated rather than concentrated in the same areas." ${ }^{2}$ To the contrary, "the city's interest in attempting to preserve the quality of life is one that must be accorded high respect," and it "must be allowed a reasonable opportunity to experiment with solutions to admittedly serious problems." ${ }^{83}$ Applying this standard, Justice Stevens, not surprisingly, rejected the constitutional challenge. ${ }^{84}$

Justice Stevens offered two justifications for this departure from the stringent standards of review ordinarily used to test content-based restrictions. First, he maintained that sexuallyexplicit movies, although not obscene, are nevertheless of relatively "low" first amendment value, ${ }^{85}$ and therefore subject to reasonable regulation. ${ }^{88}$ This analysis did not command the support of a majority of the Court, and was forcefully repudiated by Justice Stewart in dissent. ${ }^{87}$ Second, and more to the point, Justice Stevens declared that the essence of the rule prohibiting restrictions of speech "based on the content of the protected communication is the need for absolute neutrality by the government; its regulation of communication may not be affected by sympathy or hostility for the point of view being expressed by the communicator." 88 Thus, the content-based distinction in Young did not violate "the government's paramount obligation of neutrality," for the challenged restriction of sexuallyexplicit movies "is unaffected by whatever social, political, or philosophical message a film may be intended to communicate; whether a motion picture ridicules or characterizes one point of view or another, the effect of the ordinances is exactly the same." 89 According to Justice Stevens, then, subject-matter restrictions, because they are viewpoint neutral, are less troublesome than other forms of

427 U.S. at 71.

s Id.

" In upholding the ordinances, Justice Stevens emphasized (1) that there was a "factual basis" for the city's conclusion that the restriction "will have the desired effect," id. at 71; (2) that the ordinances did not have "the effect of suppressing, or greatly restricting access to, lawful speech," id. at $71 \mathrm{n} .35$; and (3) that the harm against which the ordinances were directed was only a "secondary effect" of the restricted speech, id. at 71 n.34.

ss Justice Stevens maintained that since "few of us would march our sons or daughters off to war to preserve the citizen's right to see" sexually explicit movies, "it is manifest that society's interest in protecting this type of expression is of a wholly different, and lesser, magnitude than the interest in untrammeled political debate." Id. at 70. The question whether any particular type of expression is of "low" first amendment value, and thus less than fully protected, is beyond the scope of this article. See notes $7 \& 15$ supra.

s See id. at 70-71.

${ }^{87}$ See id. at 73 n.1 (Powell, J., concurring); id. at 84-87 (Stewart, J., dissenting).

Id. at 67 .

- Id. at 70. 
content-based restrictions, and thus should be tested by less rigorous standards. Justice Stevens made no effort to explore this theory in depth or to reconcile it with the Court's prior subject-matter decisions.

Justice Powell, who cast the pivotal fifth vote to sustain the ordinances, filed a separate concurring opinion. Arguing that Young involved several unusual features making it "unique" and not analogous "to any . . . prior case," Justice Powell concluded that the ordinances were "an example of innovative land-use regulation, implicating First Amendment concerns only incidentally and to a limited extent." In discussing the factors that influenced his perception of the case, ${ }^{92}$ Justice Powell did not mention that the case involved a restriction based upon subject matter. Given the somewhat idiosyncratic nature of his analysis, it is difficult to ascertain

- Id. at 76 (Powell, J., concurring). Justice Powell emphasized, for example, that (1) the owners of the theaters had only a commercial and not a personally communicative interest in exhibiting the movies, see id. at 78 \& $n .2$; (2) the impact of the ordinances on the ability of individuals to see such movies was only "incidental and minimal," id. at 78; and (3) the city's intent was not "to restrict the communication itself because of its nature," $i d$. at 81 n.4.

"Id. at 73. Justice Powell seems to have concluded that since "there is no indication" that the ordinances would have "the effect of suppressing production of or, to any significant degree, restricting access to adult movies," id. at 77, and since the real interests of the exhibitors are commercial rather than communicative, see id. at 78 \& $\mathrm{n} .2$, "it is appropriate to analyze" the case "under the four-part test of United States v. O'Brien, 391 U.S. 367,377 (1968)." Id. at 79. Applying that test, he concluded that the ordinances were constitutional.

There are several problems with this analysis, and I should like to note them just briefly. First, Justice Powell's insistence that the ordinances would not seriously impair the ability of individuals to see these movies contrasts sharply with the long-standing principle that "one is not to have the exercise of his liberty of expression in appropriate places abridged on the plea that it may be exercised in some other place." Schneider v. State, 308 U.S. 147, 163 (1939). Accord Southeastern Promotions, Ltd. v. Conrad, 420 U.S. 546, 556 (1975). See also Virginia State Bd. of Pharmacy v. Virginia Citizens Consumer Council, Inc., 425 U.S. 748, 757 n.15 (1976); Spence v. Washington, 418 U.S. 405, 411 \& n.4 (1974). Second, even if one accepts the initial steps in Justice Powell's reasoning, he never explains why he suddenly shifts from ordinary content-based analysis to O'Brien.

Third, in applying the $O^{\prime} B r i e n$ test, Justice Powell reformulates the third and critical requirement that "the governmental interest [be] unrelated to the suppression of free speech." In his view, this requirement is satisfied so long as government does not have "an intent or purpose to restrict the communication itself because of its nature." 427 U.S. at 81 n.4. This interpretation of $O^{\prime} B r i e n$ is, I believe, fundamentally incorrect. In my view, the third requirement of $O^{\prime} B r i e n$ can never be satisfied when a law expressly draws a line based upon content. Such laws are of necessity related "to the suppression of free speech." The real purpose of this requirement, I submit, is to exclude from the O'Brien test those laws that do not draw such a line, but that nevertheless should be treated as content-based because their application is triggered by content or their passage was motivated by a hostility or.sympathy for certain content. See Ely, supra note 1, at 1496-502. Finally, even if one accepts Justice Powell's view of the third requirement of O'Brien, his conclusion that the city's motive was pure is open to question. See The Supreme Court, 1975 Term, supra note 71, at 203 n.47.

2 See note 90 supra. 
whether this factor also affected his conclusion and thus whether Justice Stevens's remarks on the issue represented the views of a majority of the Court.

Justice Stewart, writing for the four dissenters, saw Young as involving an unexceptional attempt by government "to impose a selective restraint on speech with a particular content." ${ }^{93}$ He made no effort to answer Justice Stevens's argument that, because of their apparent viewpoint neutrality, subject-matter distinctions should be handled differently from other content-based restrictions. Moreover, Justice Stewart made no mention of his own three-month-old opinion for the Court in Greer. Rather, referring to Mosley and Erznoznik, he simply assumed that subject-matter restrictions were no different from other content-based restrictions. ${ }^{94}$ Tested against the ordinary standards of content-based analysis, the ordinances, although "well-intentioned," were clearly unconstitutional..$^{95}$

As the foregoing discussion reveals, the Court has had considerable difficulty in its efforts to cope with restrictions that, although content-based, are defined in terms of expression about an entire subject rather than a particular viewpoint or idea. The Court's difficulty, I suspect, derives largely from its failure to see this class of restrictions as presenting a separate and special problem of first amendment interpretation. Indeed, the Court has for the most part been virtually oblivious to the connections between its own subjectmatter decisions, often not even citing what seem in perspective to be potentially significant, if not controlling, precedents. As a consequence, the Court has treated some of these restrictions as contentbased and others as content-neutral without in either case carefully analyzing the problem.

The consequences of this state of affairs are several. First, from the standpoint of craftsmanship, the Court's performance leaves much to be desired: the language and the reasoning of the cases are contradictory and imprecise. Second, it is at least possible that several of these cases were "incorrectly" decided, in the sense that had the Court been more thoughtful in its analysis and more aware of the connections between its decisions it might have reached dif-

"3 427 U.S. at 84 n.2 (Stewart, J., dissenting).

"See id. Justice Stewart explained Lehman and Rowan, not as subject-matter cases, but as cases involving the "special" problem of captive auditors. See id. at 86 \& n.5.

is Not surprisingly, the positions and arguments of the Justices in FCC v. Pacifica Foundation, 98 S.Ct. 3026 (1978), in which the Court upheld a restriction on profane speech, were quite similar to those in Young. This is so in part because, although a limitation on the use of profanity is not technically a subject-matter restriction, it nevertheless has many of the same attributes, including the apparent viewpoint neutrality that was so important to Justice Stevens in Young. 
ferent results. And third, to the extent that the Court was moved in any given case to uphold a restriction because it was defined in terms of subject matter, but failed to isolate this factor as critical, it might have generated a doctrine or principle that could later be used to uphold other sorts of content-based restrictions as well..$^{96} \mathrm{My}$ purpose, however, is not merely to catalogue the Court's failings, but also to offer an alternative approach to the problem. Such a task requires a closer examination of subject-matter restrictions and prevailing first amendment doctrine.

\section{A Framework for Analysis of Subject-Matter Restrictions}

How, then, should subject-matter restrictions be analyzed? Are they indistinguishable in essence from other forms of content-based restrictions and thus properly subject to the ordinarily stringent standards of content-based analysis? Are they, rather, a wholly separate form of content-based restriction, more akin in essence to content-neutral restrictions, and thus properly subject to contentneutral balancing? Or are they in some intermediate position, possessing qualities of both content-neutral and content-based restrictions, and thus properly subject to a-more variable sort of analysis? Since the content-based/content-neutral distinction seems to lie at the heart of the problem, any attempt to answer these questions should at least begin with an inquiry into the reasons underlying the doctrine that content-based restrictions are generally more threatening to our system of free expression than content-neutral restrictions and must therefore be tested against markedly more rigorous standards of justification. Once we identify the reasons for this doctrine, we can attempt to determine the extent to which subjectmatter restrictions engender similar sorts of concerns.

\section{A. The Special Dangers of Content-Based Restrictions}

Although there has been much discussion of the purposes underlying the guarantee of free speech, ${ }^{97}$ surprisingly scant attention has been paid to the related question why, within the realm of possible abridgments of free expression, we are so especially wary of restrictions based upon content. ${ }^{98}$ On the rare occasion when the

" This danger is perhaps most evident in the Court's use of the captive audience concept in Lehman and Rowan.

" See, e.g., T. Emerson, The System of Freedom of Expression 6-9 (1970); L. Tribe, supra note 1, \$§ 12-1 to -4, at 576-89; Blasi, The Checking Value in First Amendment Theory, 1977 AM. B. Foundation REsEarch J. 521; Karst, supra note 5, at 23-26.

is The values underlying protection of free expression are often threatened by contentneutral as well ds by content-based restrictions of speech. Our concern here is with the reasons 
question does come up, the answer is all too often simply taken for granted.99 The question is important, however, if subject-matter restrictions are to be placed within their proper first amendment context.

1. Marketplace of Ideas. There appear to be two primary reasons for the Court's strikingly speech-protective approach to content-based restrictions. First, because such restrictions accord differential treatment to speech because of its content, they necessarily distort the ordinary workings of the "marketplace of ideas" in a content-differential manner. Such restrictions thus leave the public with only an incomplete-and perhaps inaccurate-perception of their social and political universe. As a consequence, they tend seriously to undermine two of the principal purposes of free speech: they distort the search for truth, ${ }^{100}$ and they distort the process, so essential to the effective operation of a selfgoverning society, by which the citizen makes for himself critical decisions on matters of public policy. ${ }^{101}$

Whether a concern for preserving the "marketplace of ideas" can fairly be said to justify special treatment of content-based restrictions depends, of course, upon whether these distortions are in some sense peculiar to content-based restrictions. Content-neutral restrictions may also limit the public's access to potentially relevant information and ideas. ${ }^{102}$ But because they appear on their face to do so in a content-neutral manner, there is arguably a prima facie case that such restrictions do not have a similarly distorting effect

why content-based restrictions might be especially threatening to those underlying values.

" See, e.g., L. TrIBE, supra note 1, $\$ 12-2$, at 581 .

in The idea that a fundamental purpose of free speech is to aid in society's search for truth was first developed by Milton. See J. MILTON, AREOPAGITICA (1644), reprinted in AREOPAGrTICA AND OTHER Prose Works 1, 23-38 (1972). See also Gertz v. Robert Welch, Inc., 418 U.S. 323, 339-40 (1974); Abrams v. United States, 250 U.S. 616, 630 (1919) (Holmes, J., dissenting); J.S. MiLl, ON Liberty (1859), reprinted in The Phmosophy of John Stuart MiLl 20708 (M. Cohen ed. 1961).

iu The leading exponent of the view that the free speech guarantee is designed to facilitate intelligent self-government in a democratic system is Alexander Meiklejohn. See A. Meiklejohn, Political Freedom (1960); A. Metklejohn, Free Speech and Its Rriation to Selp-Government (1948); Meiklejohn, The First Amendment is an Absolute, 1961 Sup. CT. REv. 245 (1961). See also T. EMERson, supra note 93, at 7; Bork, Neutral Principles and Some First Amendment Problems, 47 IND. L.J. 1 (1971); Kalven, The New York Times Case: A Note on the "Central Meaning of the First Amendment," 1964 Sup. CT. REv. 191.

12 Although content-neutral restrictions exist in several forms, most directly limit the time, place, or manner of communicative activity. See, e.g., Grayned v. City of Rockford, 408 U.S. 104 (1972); United States v. O'Brien, 391 U.S. 367 (1968); NAACP v. Button, 371 U.S. 415 (1963); Schneider v. State, 308 U.S. 147 (1939). Other facially content-neutral regulations may have only an incidental-but nevertheless important-limiting effect on communicaton. See, e.g., Shelton v. Tucker, 364 U.S. 479 (1960); NAACP v. Alabama ex rel. Patterson, 357 U.S. 449 (1958). 
and thus do not as seriously inhibit the search for truth or the process of self-governance. ${ }^{103}$ This is not to say, however, that content-neutral restrictions can never have a content-differential impact. To the contrary, in at least some instances such restrictions, although content-neutral on their face, may nevertheless be selectively enforced in a content-differential manner. But to meet this concern by testing all content-neutral restrictions under the same stringent standards of review employed to test content-based restriction $\mathrm{s}^{104}$ seems more drastic a step than first amendment principles require. Thus, in its own effort to reduce the risk of selective enforcement of content-neutral restrictions, the Court has relied instead upon its vagueness and overbreadth doctrines that, by requiring even content-neutral restrictions to be narrowly drawn and carefully drafted, sharply limit the opportunities for such abuse. ${ }^{105}$ Moreover, when actually confronted with a clear case of selective enforcement, the Court has not hesitated to treat facially contentneutral restrictions as if they were in fact content-based. ${ }^{106}$

Content-neutral restrictions may also distort the marketplace of ideas in a content-differential manner when, although neutral on their face, they have de facto "unequal effects on various types of messages." 107 For example, a law prohibiting all leafletting appears content-neutral, but may in fact have a disproportionately harsh impact upon those who, for reasons of finances or ideology, do not have ready access to more conventional means of communication. ${ }^{108}$ Similarly, an apparently even-handed disclosure requirement may in fact fall more heavily upon those with controversial or unpopular views. ${ }^{109}$ Indeed, most content-neutral restrictions have at least

16s Even content-neutral restrictions that have no content-differential impact require careful analysis, for an effective system of free expression presupposes not only the absence of content censorship, but also the existence of a meaningful opportunity for the individual to communicate his views to the relevant audience. See, e.g., CBS v. Democratic Nat'l Comm., 412 U.S. 94, 193.94 (1973) (Brennan, J., dissenting) and cases cited therein; Scanlon, A Theory of Freedom of Expression, 1 Philosophy \& PUB. AFr. 204, 223 (1972); Stone, supra note 11 , at $233-34,245$.

104 A high standard of justification would reduce the risk of selective enforcement of content-neutral restrictions because, if the harm caused by the communicative activity is truly substantial, underenforcement becomes far more costly to society.

ros See, e.g., In re Primus, 436 U.S. 412, 432 (1978); Buckley v. Valeo, 424 U.S. 1,41 n.48 (1976); Grayned v. City of Rockford, 408 U.S. 104, 108-09 (1972); Papachristou v. City of Jacksonville, 405 U.S. 156 (1972); Shuttlesworth v. City of Birmingham, 394 U.S. 147 (1969).

See also Karst, supra note 5, at 30, 38-39.

in See Cox v. Louisiana, 379 U.S. 536 (1965).

${ }^{107}$ Karst, supra note 5, at 36.

los See, e.g., Martin v. City of Struthers, 319 U.S. 141, 146 (1943). See also Kalven, supra note 30 , at 30 .

109 See, e.g., Shelton v. Tucker, 364 U.S. 479 (1960); Talley v. California, 362 U.S. 60 (1960); NAACP v. Alabama ex rel. Patterson, 357 U.S. 449 (1958). 
some de facto content-differential effects. And although these effects are in most instances more remote and less direct than when the restriction is explicitly content-based, it might nevertheless seem appropriate, if we are seriously dedicated to minimizing content-differential distortions of the "marketplace," to employ content-based standards of review in all cases. The Court has attempted to handle this problem in a more moderate manner, however, taking this factor into account in the balancing process only when the particular content-neutral restriction at issue is likely to have substantial and relatively clear-cut content-differential effects. ${ }^{110}$ Viewed in this light, the desire to prevent contentdifferential distortions of the "marketplace of ideas" seems to provide a partial explanation-but only a partial explanation-of the Court's special treatment of content-based restrictions.

2. Government Impartiality. The second possible explanation of the Court's strikingly speech-protective approach to contentbased restrictions derives from the precept that it is per se impermissible for government to restrict speech because it disapproves of the message conveyed. "11 This precept is, indeed, a fundamental of first amendment jurisprudence, for any effort by the government to suppress speech because it does not like the ideas or information expressed would seem flatly to contradict three of the most important principles of free speech theory. The most familiar premise is, of course, that the system of free expression serves to promote the discovery of truth-political and otherwise. This view rests upon the assumption that, in the search for "truth," we are more likely to succeed in the long run if we rely, not upon the dictate of a government censor but, rather, upon "the power of the thought to get itself accepted in the competition of the market." 112 Any effort of government to restrict speech because it consists of a "false," "wrong," or

11 See, e.g., Buckley v. Valeo, 424 U.S. 1, 30-35, 60-84 (1976); Louisiana ex rel. Gremillion v. NAACP, 366 U.S. 293 (1961); Shelton v. Tucker, 364 U.S. 479 (1960); Talley v. California, 362 U.S. 60 (1960); Bates v. City of Little Rock, 361 U.S. 516 (1960); Martin v. City of Struthers, 319 U.S. 141 (1943). See also L. TrRB, supra note 1, $\$ 12-20$, at 683; Karst, supra note 5, at 36-42. But see United States v. O'Brien, 391 U.S. 367 (1968). Even when the Court does take the presence of a content-differential impact into account in its contentneutral balancing, it does not shift automatically to full content-based standards of review.

'II See, e.g., First Nat'l Bank v. Bellotti, 435 U.S. 765, 791 n.31 (1978); Linmark Assocs., Inc. v. Township of Willingboro, 431 U.S. 85, 97 (1977); L. Trrse, supra note $1, \S 12.5$, at 591; Bogen, The Supreme 'Court's Interpretation of the Guarantee of Freedom of Speech, 35 MD. L. REv. 555, 557 (1976); Scanlon, supra note 103; cf. United States v. O'Brien, 381 U.S. 367,377 (1968) (government regulatory interest must be unrelated to the suppression of freedom of expression).

"12 Abrams v. United States, 250 U.S. 616, 630 (1919) (Holmes, J., dissenting). See also note 100 supra. 
"bad" idea directly contravenes this basic first amendment presupposition.

A second principle flows from the observation that the free speech guarantee was designed, in part, to enable intelligent selfgovernment in a democratic system. ${ }^{113}$ As the Court has recently observed, "the people in our democracy are entrusted with the responsibility for judging and evaluating the relative merits of conflicting arguments," and "if there be any danger that the people cannot evaluate the information and arguments advanced [in the course of public debate], it is a danger contemplated by the Framers of the First Amendment."114 Any attempt by government to squelch "undesirable" ideas or information necessarily usurps the right of the people to make such decisions for themselves and thus conflicts with this central premise of the free speech guarantee.

Finally, it has long been recognized that the system of free expression, by enabling the individual to make political, social, moral, and other decisions for himself, serves in a critical way to enhance personal growth, self-realization, and the development of individual autonomy. ${ }^{115}$ Any government effort to suppress speech because the government does not agree with the idea communicated and does not trust the individual to decide "wisely" is patently inconsistent with this underlying purpose of the first amendment.

In light of the foregoing, there would seem to be ample support for the precept that it is per se illegitimate for the government to restrict speech merely because it disapproves of the message conveyed. ${ }^{110}$ What, though, does this have to do with the Court's special treatment of content-based restrictions? Although such restrictions may in some instances derive, at least in part, from government

"13 See note 97 supra.

114 First Nat'l Bank v. Bellotti, 435 U.S. 765, 792 (1978).

its See, e.g., Cohen v. California, 403 U.S. 15, 24 (1971); Whitney v. California, 274 U.S. 357, 375 (1927) (Brandeis, J., concurring); T. EMmerson, supra note 97, at 6; L. TrIBE, supra note 1, § 12-1, at 578; Scanlon, supra note 103.

III It is in some sense difficult to speak meaningfully of a distinction between government disapproval of an idea and government disapproval of the consequences that might follow from the dissemination of the idea. That is, when one does not "like" an idea, it is as often as not because one does not like what would happen if people agreed with it. As a result, it might be said that the precept here under discussion is, in fact, meaningless. The answer, I think, is to recognize that the precept is directed not only at government efforts to restrict speech because it is "wrong," but also at government efforts to restrict speech in order to prevent one specific type of "bad" consequence in particular-that is, that the speech might persuade people to act in an "undesirable" manner. Understood in this manner, the precept makes considerable sense. See, e.g., First Nat'l Bank v. Bellotti, 435 U.S. 765, 791 n.31 (1978); Linmark Assocs., Inc. v. Township of Willingboro, 431 U.S. 85, 97 (1977); Virginia State Bd. of Pharmacy v. Virginia Citizens Consumer Council, Inc., 425 U.S. 748, 770 (1976). See also Scanlon, supra note 103. 
hostility to the views suppressed, in others that factor may not have played a role at all. The problem, of course, is to separate one set of cases from the other. One approach might be simply to uphold any content-based restriction that serves a legitimate government interest. Such a standard would guarantee that there is at least some legitimate justification for the restriction. It would not, however, exclude the possibility that the real reason for the restriction was disapproval of the ideas suppressed. Since government can posit some legitimate purpose for virtually any content-based restriction, this standard would routinely permit pretextual evasions of the precept. Moreover, even if one were satisfied in any given case that the particular restriction was genuinely intended to serve the interest asserted, the possibility would nevertheless remain that the decision to adopt the restriction was in some degree coloredconsciously or unconsciously-by the illegitimate consideration. Indeed, this possibility seems very real in many cases, and any relatively lenient standard of review would fail to meet the danger squarely. ${ }^{117}$

A second possible approach to the application of the precept is to attempt to ascertain in each case whether governmental opposition to the speech in fact played any appreciable role in the decision to enact the particular content-based restriction at issue. For a variety of reasons, however, the Court has generally avoided the cumbersome process of inquiring into legislative motivation. ${ }^{118}$ Whatever the merits of that decision in other contexts, ${ }^{11}$ it seems especially compelling here. Typically, the question whether an inquiry into legislative motivation is appropriate arises when, in looking at the challenged legislation only on its face, one would ordinarily assume that there was no improper motivation, but some special circumstance or some unique contextual twist nevertheless gives rise to a suspicion that the legislation was indeed motivated by some improper consideration. ${ }^{120}$ The scrutiny of content-neutral restrictions would ordinarily follow this pattern. With respect to content-based

117 In several instances the Court has upheld, under a relatively lenient standard of first amendment review, content-based restrictions that purport to serve some asserted state interest, but that seem on closer inspection to have been designed at least partly to suppress "undesirable ideas." See, e.g., Whitney v. California, 274 U.S. 357 (1927); Gitlow v. New York, 268 U.S. 652 (1925); Pierce v. United States, 252 U.S. 239 (1920); Debs v. United States, 249 U.S. 211 (1919).

11 See, e.g., Palmer v. Thompson, 403 U.S. 217, 224-25 (1971); United States v. O'Brien, 391 U.S. 367, 382-85 (1968). But see Washington v. Davis, 426 U.S. 229 (1976).

11' For discussions of the merits of this view, see L. TRIBE, supra note 1, $\$ \S 12-5$ to -6 ; Brest, supra note 3; Ely, supra note 3.

12 See, e.g., cases cited in note 118 supra. 
restrictions, however, this pattern is reversed, for anyone with any knowledge of human nature should naturally assume that the decision to adopt almost any content-based restriction might have been affected by an antipathy on the part of at least some legislators to the ideas or information being suppressed. ${ }^{121}$ The logical assumption, in other words, is not that there is no improper motivation but, rather, because legislators are only human, that there is a substantial risk that an impermissible consideration has in fact colored the deliberative process. Thus, if the motivation behind the enactment of content-based restrictions were routinely open to question, the issue would be raised in virtually every instance. It would then be incumbent upon the courts to attempt in each case to ascertain the actual degree of improper motivation and to decide whether it vitiated the content-based restriction at issue. Such an approach seems neither sensible nor economical.

To avoid the necessity of such an inquiry in every case, one might resort to the use of presumptions. Thus, a third approach to implementing the precept would be to erect a presumption that content-based restrictions, because of their very nature, are tainted by at least the likelihood of improper motivation. This presumption might even be deemed irrebuttable, thus rendering all contentbased restrictions per se invalid. Such a presumption seems too harsh, though, for at least two reasons. First, there might be some content-based restrictions that were in fact untainted by any appreciable improper motivation. In such cases, one might permit the government to counter the presumption with proof of motivational purity. As already indicated, however, the Court has generally sought to avoid such inquiries. Moreover, in such a case the government would be attempting to prove a negative, thus exacerbating all the problems usually associated with inquiry into legislative motive. ${ }^{122}$ Second, whether or not we permit proof of motivational purity to overcome the presumption, there may be some cases in which we can be reasonably certain that the content-based restriction would have been enacted even in the absence of any improper

${ }^{121}$ Cf. Abrams v. United States, 250 U.S. 616, 630 (1919) (Holmes, J., dissenting) (suggesting that those who are certain of their power will logically attempt to suppress the expression of opposing points of view). Legislators will almost invariably have their own opinions about the merits of the speech suppressed by any particular content-based restriction, and however much they may try, it seems doubtful that they can wholly ignore those opinions when considering the desirability of the restriction.

122 The difficulties involved in such an exercise are well demonstrated by Justice Powell's rather questionable "finding" of no improper motivation in Young v. American Mini Theatres, Inc., 427 U.S. 50, $80-82$ \& n.4 (1976) (Powell, J., concurring). 
motivation. ${ }^{123}$ In such circumstances, we might conclude that the precept was not violated, or at least not violated in any significant sense, and that the restriction should thus not be set aside. This might be so, for example, when the interest served by the restriction is truly compelling and when there is no other way to protect this interest than by use of the content-based restriction. This mode of analysis, of course, resembles in important respects the stringent standards of review used by the Court to test content-based restrictions, and viewed in this light, the Court's special treatment of such restrictions may sensibly be understood as an attempt to effectuate the precept that it is per se illegitimate for government to restrict speech because it disfavors the message conveyed. ${ }^{124}$

Thus, although at first glance it seems self-evident that content-based restrictions are more threatening to the system of free expression than content-neutral restrictions, this proposition is, on closer examination, somewhat more difficult to defend than might be expected. Indeed, since content-neutral, like content-based restrictions may at times have a differential impact or reflect a latent government hostility toward certain ideas, the differences between these two types of restrictions often seem to be differences more of degree than of kind. Nevertheless, the Court's special treatment of content-based restrictions can be explained, at least generally, in terms of the uniquely distorting impact they have upon the "marketplace of ideas" and the particularly high likelihood that their passage may have been tainted by the presence of a fundamentally illegitimate motive. Although neither of these considerations, standing alone, may be sufficient to explain fully the Court's approach, ${ }^{125}$ taken together they shed considerable light upon the Court's interpretation of the first amendment and provide a basis for analyzing restrictions defined in terms of subject matter.

123 Cf. Mt. Healthy City School Dist. v. Doyle, 429 U.S. 274 (1977) (burden on school district to show it would have reached same decision to fire teacher even in the absence of protected speech).

124 See Bogen, supra note 111. As already indicated, content-neutral restrictions, precisely because they are content-neutral, do not generally involve a similar likelihood of impro. per motivation. Accordingly, they need not be tested against equally stringent standards of review. At the same time, however, the Court's refusal to inquire into possible improper motivation in this context, see United States v. O'Brien, 391 U.S. 367 (1968), is problematic. See generally note 119 supra.

${ }_{125}$ For example, a content-based distinction that has no appreciable effect on the "marketplace of ideas" might nevertheless be invalid because of the possibility that it was motivated by impermissible considerations. See Young v. American Mini Theatres, Inc., 427 U.S. 50, 76-82 (1976) (Powell, J., concurring). 


\section{B. Principles of Adjudication for Subject-Matter Restrictions}

In attempting to decide how best to deal with the problem of subject-matter restrictions, a central concern is whether they pose a substantially less serious threat to the system of free expression than the more familiar forms of content-based restrictions. If so, it may be that like content-neutral restrictions they need not be subjected to the rigorous standards of justification ordinarily employed to test content-based restrictions.

At least a plausible case can be made for less stringent treatment. As indicated earlier, the Court's rigorous approach to content-based restrictions stems in part from the realization that such restrictions have an especially potent content-differential impact upon the "marketplace of ideas." This distortion of the "marketplace" is of concern because it may result in the "mutilation of the thinking process of the community,"126 thus impairing effective self-governance and the search for "truth." Subject-matter restrictions also distort the "marketplace of ideas" in a content-differential manner. But because they are at least facially viewpoint-neutral, the potential harm in this regard is somewhat more remote. Although not without difficulties, viewpointneutral restrictions directed against all speech relating to an entire subject do not have the same sort of skewing effect on "the thinking process of the community" as restrictions directed specifically against speech taking a particular side in an ongoing debate. Moreover, because of their apparent viewpoint-neutrality, subject-matter restrictions seem much less likely than other forms of content-based restrictions to be the product of governmental hostility to the ideas or information suppressed. In general, one is more likely to be hostile to speech espousing a specific point of view than to speech about an entire subject. As a result, one might, with some force, argue that subject-matter restrictions are in general less threatening than other sorts of content-based restrictions and, like content-neutral restrictions, need not be subjected to the most stringent standards of review.

Although this argument has a certain surface appeal, it fails to recognize that the Court, particularly in recent years, has been reluctant to embrace broad new exceptions to its ordinarily rigorous approach to content-based restrictions. ${ }^{227}$ The concern, of course, is

126 A. Meiklejohn, Political Freedom 27 (1960).

127 See, e.g., First Nat'l Bank v. Bellotti, 435 U.S. 765 (1978) (the corporate identity of speaker does not deprive otherwise protected speech of its protection); Virginia State Bd. of Pharmacy v. Virginia Citizens Consumer Council, Inc., 425 U.S. 748 (1976) (commercial 
that once one accepts such erosion, the slope is slippery indeed. If subject-matter restrictions are exempt from ordinary content-based analysis because of their apparent viewpoint neutrality, what about other arguably viewpoint-neutral restrictions? ${ }^{128}$ Should the door be opened to an inquiry in each case as to whether the particular content-based restriction at issue is in fact viewpoint-neutral? As is often the case when dealing with a right as sensitive to limitation as free expression, adequate protection can be assured only by deliberate overprotection. It may well be, then, that the better part of wisdom in this context is to leave the door shut completely. But if any exemption at all is allowed, it should be only after the most searching scrutiny of the risks involved.

To aid in understanding those risks here, it may be helpful to divide subject-matter restrictions into two categories. The first comprises subject-matter restrictions defined in terms of speech about a specific issue or, perhaps, about a relatively narrow cluster of issues. The Mosley ordinance, with its special focus on labor speech, is an example. ${ }^{128}$ Other examples include laws prohibiting corporations from expressing publicly their views on issues concerning taxation of individuals, ${ }^{130}$ forbidding teachers to discuss publicly matters subject to collective bargaining, ${ }^{131}$ or banning street demonstrations concerning the propriety of the Vietnam war. Like all subjectmatter restrictions, these relatively circumscribed restrictions ap-

speech protected by first amendment); Cohen v. California, 403 U.S. 15 (1971) (profanity protected by first amendment); Watts v. United States, 394 U.S. 705 (1969) (hyperbolic threat protected by first amendment). See also FCC v. Pacifica Foundation, 98 S.Ct. 3026 (1978) (Court declined to exempt profanity from ordinary content-based analysis); Young v. American Mini Theatres, Inc., 427 U.S. 50 (1976) (Court declined to exempt sexually explicit speech from ordinary content-based analysis).

${ }^{128}$ Claims of viewpoint neutrality might be made, for example, with respect to restrictions on the use of profanity, see FCC v. Pacifica Foundation, 98 S.Ct. 3026, 3028 n.22 (1978) (Stevens, J.), gag orders designed to protect criminal defendants, restrictions on the press in order to redress "invasions of privacy," and the law of defamation, see L. TRIBE, supra note $1, \S 12-13$, at 641 .

123 The restriction in Mosley represents a special case. On its face it is the broadest of the restrictions considered in the decisions, banning all speech except labor speech. It thus closely resembles a content-neutral restriction. At the same time, the very breadth of the restriction, when coupled with the narrow exception, means that the restriction singles out one particular kind of speech for favorable treatment. It is, however, no more legitimate for the government to favor certain ideas in this manner than to disfavor them. That such a restriction bans other opinions in addition to those in direct competition with the favored speech hardly reduces the threat of prejudice to the marketplace of ideas or the danger of government partiality. A law banning all speech except that by Democrats is no better-indeed is probably worse-than one banning all speech by Republicans. The basic principles should be no different in one case from what they would 'be in the other.

iso See First Nat'l Bank v. Bellotti, 435 U.S. 765 (1978).

ist See City of Madison, Joint School Dist. No. 8 v. Wisconsin Employment Relations Comm'n, 429 U.S. 167 (1976). 
pear on their face to be viewpoint-neutral. In practice, however, these restrictions will often disadvantage one "side" of an issue more than the other, depending upon which "side" is more likely to be affected by the restriction. In the street demonstration example, for instance, the restriction, although viewpoint-neutral on its face, would in fact have had a more severe impact upon critics of the Vietnam war than upon its supporters, for critics relied more heavily upon this mode of communication. Similarly, in the taxation and collective bargaining cases, the Court itself has recognized in passing that these seemingly viewpoint-neutral restrictions may have viewpoint-differential effects. ${ }^{132}$ The question, then, is whether the de facto, viewpoint-differential impact these sorts of restrictions often have poses a significant enough danger to offset their facial viewpoint neutrality, which suggests that they should, like contentneutral restrictions, be exempt from the ordinarily stringent standards of content-based analysis.

At the outset, it should be recalled that many content-neutral restrictions will also have precisely this sort of de facto effect. ${ }^{133}$ For example, a content-neutral law banning all street demonstrations will have exactly the same viewpoint-differential impact on the war issue as a more limited subject-matter restriction directed specifically against speech about the war. As noted earlier, however, the mere existence of this sort of de facto impact usually will not trigger full content-based analysis, although the Court will weigh this factor in testing the constitutionality of content-neutral restrictions. It may be, then, that a similar approach should govern our analysis of these narrowly defined subject-matter restrictions.

There is, however, a potentially critical difference between content-neutral restrictions and the type of subject-matter restriction under discussion here. Whereas narrowly defined subjectmatter restrictions will have a viewpoint-differential impact upon only a single issue or, at most, a relatively narrow class of issues, content-neutral restrictions will often have such an impact upon a broad range of largely unrelated issues. In the street demonstration context, for example, the content-neutral restriction may have a de facto viewpoint-differential impact, not only upon the war issue, but also upon such diverse issues as abortion, the rights of Nazis, homosexuality, nuclear energy and the equal rights amendment. Although this result may seem to make content-neutral restrictions more problematic, in fact the opposite may be true. The very perva-

132 See First Nat'l Bank v. Bellotti, 435 U.S. 765, 784-86 (1978); City of Madison, Joint School Dist. No. 8 v. Wisconsin Employment Relations Comm'n, 429 U.S. 167, 175-76 (1976).

13 See text at notes 107-110 supra. 
siveness of the distorting impact of such restrictions significantly reduces the risk that they were actually adopted in an effort to disadvantage any particular viewpoint. The more diffuse the impact, the greater the probability that the restriction serves a governmental purpose unrelated to the suppression of disfavored ideas. ${ }^{134}$ With respect to narrowly defined subject-matter restrictions, however, the viewpoint-differential effect is sharply limited in scope, thus increasing the risk of improper legislative motivation.

Accordingly, whereas content-neutral restrictions ordinarily threaten only the first amendment concern for preserving the marketplace of ideas, and then only indirectly, narrowly defined subject-matter restrictions having a clear viewpoint-differential impact seem to implicate directly both of the concerns underlying the Court's special treatment of content-based restrictions. ${ }^{135}$ The only remaining question, then, is whether all narrowly defined subject-matter restrictions should be tested by standards of content-based analysis or, rather, whether such standards should apply only when there is a demonstrable viewpoint-differential effect. The point is arguable, but the former approach seems preferable. Given the relatively high likelihood of a viewpoint-differential effect when the restriction is narrowly drawn, the application of strict standards in such cases, rather than an attempt to treat the issue on a case-by-case basis, seems most consistent with the general presumption in favor of clarity and ease of administration in the first amendment area.

The value of this approach is especially apparent with respect to restrictions limiting expression because of its concern with sex. Indeed, it is particularly misleading to argue, as did Justice Stevens in Young, that such restrictions should be examined with deference because they apply without regard to the "social, political, or philosophical message [the speech is] intended to communicate."136 As a practical matter, the speech suppressed by restrictions such as those involved in Rowan, Erznoznik, and Young will almost invariably carry an implicit, if not explicit, message in favor of more re-

13 See Railway Express Agency v. New York, 336 U.S. 106, 112-13 (1949) (Jackson, J., concurring); Kalven, supra note 30 , at 30 ; Karst, supra note 5 , at 67.

135 This analysis indicates that, at least in this context, a differential impact alone is not sufficient to trigger full content-based analysis. The Court's treatment of content-neutral restrictions is generally consistent with this conclusion. This treatment suggests that the differential-impact concern is at least arguably subordinate to the improper motivation concern. I should note, too, that the analysis in the text seems consistent with the Court's tendency, in testing the constitutionality of content-neutral restrictions, to give added weight to the viewpoint-differential impact as the specificity of the impact increases. See cases cited in notes 109-110 supra.

136 Young v. American Mini Theatres, Inc., 427 U.S. at 70. 
laxed sexual mores. Such restrictions, in other words, have a potent viewpoint-differential impact. In a more subtle sense, moreover, the form and content of this sort of expression are inseparable. In our society, the very presence of sexual explicitness in speech seems ideologically significant, without regard to whatever other messages might be intended. To treat such restrictions as viewpoint-neutral seems simply to ignore reality. Finally, in terms of the improper motivation question, a large percentage of citizens apparently feel threatened by nonobscene, sexually-explicit speech and believe it to be morally reprehensible. If it were not for the Court's relatively narrow construction of the obscenity concept, much of this speech would undoubtedly be banned outright. Thus, any restriction along these lines will carry an extraordinarily high risk that its enactment was tainted by this fundamentally illegitimate consideration. Such restrictions, although superficially viewpoint-neutral, pose a uniquely compelling case for content-based scrutiny.

The second category of subject-matter restrictions consists of those subject-matter restrictions that are directed against broad classes of speech, cutting across a wide spectrum of issues. Restrictions such as those in CBS and Lehman, disfavoring all noncommercial, public-issue speech, and those in Buckley, Greer, Broadrick, and Letter Carriers, disfavoring all partisan political speech, are illustrative. ${ }^{137}$ Unlike the class of narrowly defined restrictions, such statutes possess what may be the most important attribute of content-neutral restrictions. That is, although such a statute may at times have de facto, viewpoint-differential effects, those effects are likely to be spread over a fairly wide range of issues, thus mitigating the risk that the restriction is tainted by an improper legislative motivation directed against a particular viewpoint. For example, although a ban on any partisan political speech on a military base may tend to disadvantage those candidates who rely more heavily upon this sort of nonmedia communication, ${ }^{138}$ that effect exists without regard to whether the candidate is a liberal or libertarian, a Socialist or Nazi. Moreover, a content-neutral ban on all speeches on the base would have the exact same de facto, viewpoint-differential impact. These same observations hold true not only with respect to Greer, but also with respect to Buckley, Broadrick, Letter Carriers, and, I suspect, almost any restriction

${ }^{137}$ There is, of course, some ambiguity in the distinction between narrowly and broadly defined restrictions. As a practical matter, however, the latter category is likely to consist almost exclusively of the restrictions identified in the text as broadly defined.

${ }^{138}$ See Spock v. David, 502 F.2d 953, 956 (3d Cir. 1974); Spock v. David, 469 F.2d 1047, 1056 (3d Cir. 1972). 
on partisan political speech. The point, of course, is not that these possible viewpoint-differential effects are unimportant. To the contrary, even in the context of content-neutral restrictions, they can result in invalidation of the legislation. ${ }^{139}$ The point is rather that this type of subject-matter restriction poses problems virtually indistinguishable from those posed by content-neutral restrictions.

Subject-matter restrictions directed against all noncommercial, public issue speech are somewhat more problematic. Typically, a content-neutral restriction will have a differential impact because it deprives all speakers of a resource or communicative opportunity that is more valuable to some speakers than to others. Although restrictions directed against partisan political speech also follow this pattern, the differential impact of restrictions directed against noncommercial, public-issue speech has an additional component. For example, the exclusion of public-issue advertisements from the vehicles in Lehman had a de facto, viewpoint-differential impact identical to that which a content-neutral exclusion would produce. But, since commercial advertisements frequently carry implicit political messages, some viewpoints on some public issues will effectively be communicated despite the seemingly viewpoint-neutral ban, ${ }^{140}$ thereby producing an additional level of sub rosa, viewpointdifferential effects. The basic nature of those effects, however, is unchanged-they still occur over a wide range of issues, thus reducing the likelihood that the restriction may actually have been aimed at particular viewpoints. Although ultimately only a matter of degree, the similarity to content-neutral restrictions seems to remain dominant. ${ }^{141}$

It may be then, that subject-matter restrictions falling within the second category should be tested by content-neutral balancing

139 See authorities cited in notes 109-110 supra.

iv In a situation similar to that in Lehman, the California Supreme Court offered several examples of the differential impact such restrictions may have:

A cigarette company is permitted to advertise the desirability of smoking its brand, but a cancer society is not entitled to caution by advertisements that cigarette smoking is injurious to health. A theater may advertise a motion picture that portrays sex and violence, but the Legion for Decency has no right to post a message calling for clean films. A lumber company may advertise its wood products, but a conservation group cannot implore citizens to write to the President or Governor about protecting our natural resources. An oil refinery may advertise its products, but a citizens organization cannot demand enforcement of existing air pollution statutes. An insurance company may announce its available policies, but a senior citizens' club cannot plead for legislation to improve our social security program.

Wirta v. Alameda-Contra Costa Transit Dist., 68 Cal. 2d 51, 57-58, 434 P.2d 982, 986-87, 64 Cal. Rptr. 430, 434-35 (1967).

iI This evaluation represents a possible step back from a position I took several years ago. See Stone, supra note 11, at 277-78. 
rather than by the more rigorous standards of content-based review. Even if such an approach is accepted, though, the fact that the restriction at issue is defined in terms of subject matter, and is not in fact content-neutral, should nevertheless play a central role in the analysis. That is, the state must explain not only why it restricted the speech it restricted, but also why it failed to restrict the speech it exempted from the restriction. It must, in other words, justify the content-based distinction. Such justification is necessary, not so much because the distinction may pose a threat to the interests underlying the special treatment of content-based restrictions, but rather because the very existence of the content-based distinction tends to undercut the state's showing, required even in the context of content-neutral balancing, that the restriction is designed to serve some substantial governmental purpose. ${ }^{142}$

The degree to which this problem exists varies considerably from case to case. In Lehman, for example, the city attempted to justify its prohibition on the display of public issue advertisements on the ground that the prohibition was necessary to protect captive commuters from unwanted exposure to unpleasant messages. This argument loses much of its force, however, when one recognizes that, as a class, "[c]ommercial advertisements may be as offensive and intrusive to captive audiences as any political message." 143 The apparent underinclusiveness of the restriction would thus seem largely to undermine the state's claim that the prohibition of public issue speech can be justified by reference to the interest asserted. At the other extreme are restrictions defined in terms of subject matter that seem to pose few, if any, problems of underinclusiveness. In Broadrick, Letter Carriers, and Buckley, for example, the concerns underlying the challenged restrictions seem to derive almost exclusively from partisan political speech. Finally, cases such as $C B S$ and Greer seem to occupy the middle ground between these extremes.

The difficulties in this analysis may suggest that the most prudent course is simply to test all subject-matter restrictions by the ordinarily stringent standards of content-based analysis. Clarity and simplicity are important values in first amendment jurisprudence, and acceptance of even a narrow sacrifice of those values in this context might have unwelcome, long-range consequences. Yet,

112 The degree of scrutiny involved in this inquiry varies with the circumstances. See authorities cited in note 2 supra. For the reasons for requiring such a showing, see note 103 supra.

"4 Lehman v. City of Shaker Heights, 418 U.S. at 308 (Douglas, J., concurring); see id. at 319; Stone, supra note 11, at 279. 
as evidenced by its decisions, the Court is inclined to view restrictions falling within the second category with some lenity, and there is a reasonably sound analytical basis for that view. Indeed, whatever other objections are lodged against them, it would be a bit jarring to learn that the statutes in Buckley, Broadrick, and Letter Carriers had been held unconstitutional under the first amendment because they were limited in application to only partisan political speech.

\section{Conclusion}

The Supreme Court has failed to recognize subject-matter restrictions as a separate class of restraints on speech. As a consequence, the Court has in some cases treated the subject-matter restriction as if it were indistinguishable from other sorts of contentbased restrictions, while in others it has effectively disregarded the subject-matter restriction entirely and thus analyzed the challenged legislation or regulation as if it were content-neutral. Moreover, apart from a few rather obvious and seemingly casual observations, the Court has made little effort to place the problem in its proper first amendment context or to analyze it in any real depth.

Although the differences between content-based and contentneutral restrictions are more elusive than might be expected, and are often only differences of degree, such differences do exist, and the Court's exacting scrutiny of content-based restrictions can be explained and justified. Subject-matter restrictions pose a particularly intriguing and useful puzzle, for they seem to exist in a middle world, sharing some characteristics with both of the more common forms of restrictions. It is largely for this reason that the Court has had so much difficulty in its efforts to come to grips with the subject-matter puzzle. The analysis offered here is intended at least to point us in the right direction. 